Jttp://journal.unnes.ac.id/sju/index.php/jlj

\title{
KEEFEKTIFAN MODEL QUANTUM TEACHING TERHADAP HASIL DAN AKTIVITAS BELAJAR PKn KELAS IV
}

\section{Ketut Alif Wijayanto ${ }^{\bowtie}$ Farid Ahmadi}

Jurusan Pendidikan Guru Sekolah Dasar, Fakultas Ilmu Pendidikan, Universitas Negeri Semarang, Indonesia

\begin{tabular}{l} 
Info Artikel \\
\hline Sejarah Artikel: \\
Diterima \\
Oktober 2017 \\
Disetujui November \\
2017 \\
Dipublikasikan \\
Desember 2017 \\
\hline Keywords: \\
activity in learning \\
outcomes; learning \\
activities; \\
Quantum \\
Teaching model.
\end{tabular}

\begin{abstract}
Abstrak
Penelitian ini dilatar belakangi oleh pembelajaran PKn kelas IV di SD Gugus Kartini yang belum optimal karena pembelajaran masih bersifat konvensional sehingga menyebabkan hasil belajar PKn rendah. Tujuan penelitian ini adalah untuk menguji keefektifan model Quantum Teaching mengunakan powerpoint terhadap hasil dan aktivitas belajar PKn kelas IV. Jenis penelitian ini adalah penelitian eksperimen semu dengan desain nonequivalent control group design. Teknik pengumpulan data dengan tes, observasi, dan dokumentasi. Analisis data menggunakan uji normalitas, uji homogenitas, uji perbedaan rata-rata, dan uji gain. Hasil penelitian menunjukkan bahwa (1) thitung lebih besar jika dibandingkan tabel $(3,368>2,000)$ berarti terdapat perbedaan posttest antara kelas eksperimen dan kelas kontrol yaitu kelas eksperimen lebih tinggi daripada kelas kontrol. Ratarata posttest kelas eksperimen sebesar 78,79, sedangkan kelas kontrol sebesar 69,24. (2) Aktivitas siswa kelas eksperimen mencapai kriteria sangat baik sedangkan kelas kontrol hanya sampai kriteria baik. Simpulan penelitian ini adalah model Quantum Teaching mengunakan powerpoint lebih efektif dan signifikan terhadap hasil dan aktivitas belajar PKn kelas IV.
\end{abstract}

\begin{abstract}
This study was underlied by Civic Education learning on fourth grade in SD Gugus Kartini which has not optimal yet because the learning is still conventional so that causing the learning outcomes of Civic Education is low. The purpose of this study is to examine the effectiveness of Quantum Teaching model using powerpoint on the outcomes and the Civic Education learning activities of the fourth grade. The research is a quasi-experimental research design with nonequivalent control group design. Data collection techniques by testing, observation and documentation. Analysis of the data by using normality test, homogeneity test, independent samples t-test, and gain test. The results showed that (1) tarithmetic was greater than table $(3,368>2,000)$ it means there was a difference of the posttest between experimental class and control class that was the experimental class was higher than the control class. The posttest average of the experimental class was 78.79, while the control class was 69.24. (2) The students activities of the experimental class gained very excellent criteria whereas the control class only gained good criteria. The conclusion of this study is the Quantum Teaching model using powerpoint is more effective and significant on the outcomes and on the learning activities of Civic Education of the fourth grade.
\end{abstract}

(C) 2017 Universitas Negeri Semarang

\footnotetext{
Alamat korespondensi:

Kunden Timur RT 03 RW II, Wirosari, Grobogan- Jawa Tengah

E-mail: ketut.nagawangsa@gmail.com
}

ISSN 2252-6366 


\section{PENDAHULUAN}

Menurut Undang-Undang Nomor 20 tahun 2003 pasal 1 "pendidikan adalah usaha sadar dan terencana untuk mewujudkan suasana belajar dan proses pembelajaran agar siswa secara aktif mengembangkan potensi dirinya untuk memiliki kekuatan spiritual keagamaan, pengendalian diri, kepribadian, kecerdasan, akhlak mulia, serta keterampilan yang diperlukan dirinya, masyarakat, bangsa, dan negara". Berdasarkan uraian tersebut, pendidikan penting diterapkan pada setiap mata pelajaran untuk mengembangkan potensi dari siswa. Salah satunya diterapkan dalam mata pelajaran PKn. Tujuan PKn dalam KTSP yaitu: (1) berpikir kritis, rasional, dan kreatif dalam menanggapi isu kewarganegaraan; berpartisipasi aktif dan bertanggung jawab, bertindak cerdas dalam kegiatan bermasyarakat, berbangsa, bernegara, serta anti korupsi; (3) berkembang secara positif dan demokratis untuk membentuk diri agar dapat hidup bersama dengan bangsa-bangsa lainnya; (4) berinteraksi dengan bangsa-bangsa lain dalam pencaturan dunia.

Tujuan PKn tersebut sudah sesuai dengan perkembangan ilmu pengetahuan secara global. Namun kenyataannya, masih banyak kualitas pembelajaran PKn di sekolah yang belum menunjukkan hasil yang diharapkan. Berdasarkan pra penelitian yang dilakukan di SDN Gugus Kartini Kecamatan Wirosari Kabupaten Grobogan melalui data hasil belajar, observasi, dan wawancara ditemukan informasi bahwa pembelajaran PKn masih rendah karena selama pembelajaran guru masih menggunakan model konvensional yaitu metode ceramah dan tanya jawab. Siswa belum diarahkan untuk belajar dengan kehidupan dunia nyata sehingga kemampuan siswa dalam berpikir kritis dan kreatif menjadi kurang dalam materi globalisasi.
Permasalahan tersebut juga didukung dengan data kuantitatif di SDN Gugus Kartini Kecamatan Wirosari Kabupaten Grobogan. Data hasil belajar UAS menunjukkan masih banyak siswa yang belum mencapai KKM yang ditetapkan yaitu 75. Rata-rata nilai UAS dari SDN Gugus Kartini Kecamatan Wirosari Kabupaten Grobogan adalah 73,58. Ditunjukkan melalui data hasil belajar SDN 01 Tanjungrejo, SDN 02 Tanjungrejo, dan SDN 01 Gedangan.. Secara keseluruhan $46,30 \%$ siswa kelas IV SDN Gugus Kartini Kecamatan Wirosari Kabupaten Grobogan mendapat nilai di atas KKM, sedangkan $53,70 \%$ siswa mendapat nilai di bawah KKM.

Berdasarkan uraian tersebut, perlu adanya model pembelajaran yang dapat memperbaiki kualitas pembelajaran dan dipandang efektif terhadap hasil belajar PKn materi globalisasi yaitu Quantum Teaching. Duch (dalam Shoimin, 2014:130) Quantum Teaching adalah penggubahan belajar yang meriah, dengan segala nuansanya. Quantum teaching juga menyertakan segala kaitan antara interaksi, dan perbedaan yang memaksimalkan momen belajar. Quantum teaching berfokus pada hubungan dinamis pada lingkungan kelas, interaksi yang mendirikan landasan dan kerangka untuk belajar (Aris Shoimin, 2014:136) .

Djamarah (2010:38) mengatakan belajar adalah perubahan yang terjadi di dalam diri seseorang setelah berakhirnya melakukan aktivitas belajar. Walaupun kenyataannya tidak semua perubahan termasuk kategori belajar. Menurut Rifa'i (2012:69), hasil belajar yaitu perubahan perilaku yang diperoleh siswa setelah mengalami kegiatan belajar. Hasil belajar Pkn materi globalisasi kelas IV dibatasi pada ranah kognitif mencakup mengingat (C1), memahami (C2), mengaplikasikan (C3), menganalisis (C4)

Penelitian yang mendukung dalam pemecahan masalah ini adalah penelitian dari 
Sukorudaningtyas tahun 2016 dengan judul"Penerapan Metode Quantum Teaching Pada Materi Ajar Tentang Sistem Pemerintahan Pusat"". Hasil penelitian menunjukkan bahwa yang pertama bahwa ada peningkatan kualitas proses pembelajaran $\mathrm{Pkn}$, setelah diadakan tindakan kelas dengan metode Quantum Teaching. Hal itu dapat ditunjukkan dengan meningkatnya aktivitas belajar siswa sebelum dan sesudah tindakan. Sebelum dilaksanakan tindakan aktivitas belajar mencapai $20 \%$, Siklus I sebanyak 10 siswa( 66,66\%) aktivitas belajarnya termasuk baik dan Siklus II sebanyak 14 siswa $(93,33 \%)$ aktivitas belajarnya termasuk dalam kategori baik.

Penelitian lain yang mendukung adalah penelitian yang dilakukan oleh Muhammad Kholisul Fatikhin dan M. Kristanto Volume 1 Nomor 2 halaman 123-127 tahun 2014 dimuat dalam jurnal Mimbar Sekolah Dasar dengan judul "Keefektifan Model Quantum Teaching Terhadap Hasil Belajar Tematik Integratif Peserta Didik Kelas IV MII". Hasil penelitiannya menunjukkan bahwa Hasil penelitian menunjukkan bahwa peserta didik yang dikenai model Quantum Teaching memperoleh nilai rata - rata 75,55, dan jumlah 20 peserta didik yang tuntas dengan persentase ketuntasan 95\%. Sementara peserta didik yang mendapat metode ceramah memperoleh ratarata 70,45 , dan jumlah 20 peserta didik yang tuntas dengan persentase ketuntasan $70 \%$.

Permasalahan dalam penelitian ini adalah (1) apakah pembelajaran PKn menggunkan pembelajaran Quantum Teaching menggunakan powerpoint efektif terhadap hasil belajar materi globalisasi Kelas IV SD di Gugus Kartini Kecamtan Wirosari Kabupaten Grobogan?; (2) bagaimanakah aktivitas siswa dalam pembelajaran PKn materi globalisasi dengan model Quantum Teaching menggunakan powerpoint kelas IV SD di Gugus Kartini Kecamtan Wirosari Kabupaten Grobogan?
Tujuan penelitian ini adalah

Mendeskripsikan keefektiftan model pembelajaran Quantum Teaching menggunakan powerpoint dengan model Konvensional terhadap hasil belajar PKn materi globalisasi pada siswa kelas IV SD Di Gugus Kartini Kecamtan Wirosari Kabupaten Grobogan; (2) Mendeskripsikan aktivitas siswa dalam pembelajaran PKn pada materi globalisasi dengan Model Quantum Teaching menggunakan powerpoint kelas IV SD Di Gugus Kartini Kecamtan Wirosari Kabupaten Grobogan.

\section{METODE PENELITIAN}

Jenis penelitian ini menggunakan penelitian eksperimen semu (quasi experimental). Desain yang digunakan yaitu desain Nonequivalent Control Group Design. Desain Nonequivalent Control Group Design dari Sugiyono(2015:116) sebagai berikut:

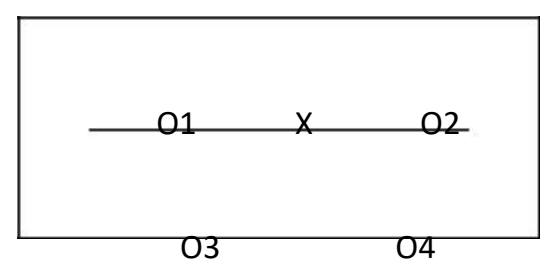

Gambar 1. Desain Nonequivalent Control Group Design

Populasi dalam penelitian ini adalah seluruh siswa kelas IV SDN Gugugs Kartini Kabupaten Grobogan dengan jumlah 221 siswa. Teknik pengambilan sampel yang digunakan yaitu simple random sampling. Teknik pengumpulan data menggunakan tes, observasi dan dokumentasi. Selanjutnya, analisis data menggunakan uji normalitas, uji homogenitas, uji hipotesis, dan uji gain. Data deskriptif berupa hasil observasi aktivitas siswa pada pembelajaran PKn materi Globalisasi dengan model Quatum Teaching menggunakan powerpoint, dianalisis dengan analisis deskriptif kuantitatif dengan rumus persentase. 


\section{HASIL DAN PEMBAHASAN}

Analisis Data Awal

Pretest dilakukan untuk mengetahui kemampuan awal siswa pada pembelajaran PKn. Rata-rata pretest kelas eksperimen sebesar 62,06, sedangkan rata-rata pretest kelas kontrol sebesar 60,28 . Hasil pretest menunjukkan bahwa skor pada pembelajaran PKn berdistribusi normal dan homogen. Jika dilihat dari skor pretest antara kedua kelompok tersebut, menunjukkan bahwa tingkat kemampuan dari siswa kelas eksperimen maupun kelas kontrol cenderung sama sebelum diberikan perlakuan yang berbeda.

Berdasarkan tingkat ketuntasan nilai pretest kelas eksperimen dan kontrol. Data tersebut menunjukkan bahwa kemampuan awal siswa terhadap materi globalisasi antara kelas eksperimen dan kontrol tergolong rendah.

\section{Analisis Data Akhir}

Posttest dilakukan untuk mengetahui hasil dari perlakuan yang diberikan terhadap kedua kelas. Perlakuan kelas eksperimen menggunakan model Quantum Teaching menggunakan powerpoint, sedangkan kelas kontrol menggunakan model konvensional yaitu metode ceramah dan tanya jawab. Rata-rata posttest kelas eksperimen sebesar 78,79, sedangkan kelas kontrol sebesar 69,24. Hasil posttest menunjukkan bahwa data akhir skor posttest PKn pada kelas eksperimen dan kelas kontrol berdistribusi normal dan homogen. Setelah melakukan uji normalitas dan homogenitas, dilanjutkan dengan uji perbedaan rata-rata menggunakan independent samples t-test. Hasil perhitungan uji perbedaan rata-rata disajikan dalam tabel sebagai berikut:

Tabel 1 Uji Perbedaan Rata-Rata Data Posttest

Hasil Belajar Siswa Kelas IV SDN 02

Tanjungrejo dan SDN 01 Tanjungrejo

Berdasarkan tabel

1, menunjukkan bahwa

thitung sebesar 3,363 lebih besar jika
Kelas thiung ttabel Df Sig. (2 tailed)

\begin{tabular}{lllll}
\hline Eksperimen & 3,363 & 2,000 & 60 & 0,001
\end{tabular}

Kontrol

dibandingkan dengan ttabel yaitu sebesar 2,000 $(3,363>2,000)$, artinya Ha diterima. Ha diterima berarti hasil belajar PKn dengan model Quantum Teaching menggunakan powerpoint lebih tinggi daripada hasil belajar PKn dengan model konvensional yaitu metode ceramah dan tanya jawab. Hasil posttest menunjukkan bahwa ratarata antara kelas eksperimen lebih tinggi daripada kelas kontrol.

Hasil pretest dan posttest dari kelas eksperimen maupun kelas kontrol dihitung dengan menggunakan uji gain. Tujuannya yaitu untuk mengetahui peningkatan rata-rata hasil pretest dan posttest masing-masing kelas. Hasil perhitungan uji gain disajikan dalam tabel sebagai berikut:

Tabel 2 Data Peningkatan Skor Pretest dan

Posttest Siswa Kelas IV SDN Gugus Kartini

Wirosari Grobogan

\begin{tabular}{lllll}
\hline Kelas & $\begin{array}{l}\text { Mean } \\
\text { Pretest }\end{array}$ & $\begin{array}{l}\text { Mean } \\
\text { Posttest }\end{array}$ & $\begin{array}{l}\text { Gain } \\
\text { Score }\end{array}$ & Kategori \\
\hline Eksperimen & 62,06 & 78,79 &, 4409 & Sedang \\
Kontrol & 61,28 & 69,24 & 0,2255 & Rendah \\
\hline
\end{tabular}

Berdasarkan tabel 2, diperoleh hasil gain kelas eksperimen yaitu 0,4409 dengan kategori sedang, sedangkan kelas kontrol yaitu 0,2255 dengan kategori rendah. Berdasarkan hasil tersebut, menunjukkan bahwa kelas eksperimen dengan model Quantum Teaching menggunakan powerpoint memiliki peningkatan rata-rata lebih tinggi daripada kelas kontrol dengan model konvensional yaitu metode ceramah dan tanya jawab. Penggunaan model Quantum Teaching menggunakan powerpoint efektif digunakan saat kegiatan pembelajaran.

Berdasarkan kajian empiris yang mendukung penelitian adalah penelitian yang dilakukan olehSri Winarti Durant, dkk. Volume 2 Nomor 3 tahun 2014 dimuat dalam Jurnal 
Kreati Tadulako dengan judul "Meningkatkan Hasil Belajar IPA Khususnya Materi Energi dan Perubahannya Melalui Pembelajaran Quantum Teaching di Kelas V SDN Inpres Matamaling". Hasil penelitian menunjukkan bahwa terjadi peningkatan hasil belajar, dari siklus I ke siklus II. Peningkatan tersebut dibuktikan dengan hasil analisis tes hasil belajar siswa yang diperoleh pada siklus I, yakni siswa yang tuntas 15 dari 20 siswa atau persentase ketuntasan klasikal sebesar $75 \%$ dan daya serap klasikal 72,2\%, serta aktivitas siswa dalam kategori efektif. Pada siklus II siswa yang tuntas 20 dari 20 siswa atau ketuntasan klasikal 100\% dan dan daya serap klasikal sebesar $87,7 \%$, serta aktivitas siswa berada dalam kategori sangat efektif.

Penelitian yang dilakukan oleh Fitri Adawiyah, dkk. Volume 3 Nomor 2 dimuat dalam Jurnal Antologi tahun 2015 dengan judul "Aplication Quantum Teaching Model to Develoved Student Activity to Socal Studies inElementary School". Hasil menunjukkan bahwa model model pembelajaran Quantum dalam kegiatan belajar pada siswa mempunyai peningkatan Dalam siklus I nilai rata- rata aktifitas belajar siswa adalah 42,4 , dalam siklus II rata- rata nilai pada aktifitas belajar siswa adalah 61,04 , dalam siklus III rata- rata nilai pada aktifitas belajar siswaadalah74,36. Rata- rata nilai pada kelompok siklus I adalah 57, dalam siklus II adalah 74,78, di siklus III 77,82.

Penelitian yang dilakukan oleh Dewa Putu Cahyadi, dkk. Volume 2 Nomor 1 tahun 2014 dimuat dalam Jurnal Mimbar PGSD Universitas Ganesha dengan judul “ Implementasi Model Quantum Teaching Berbantuan Snowball Trhowing untuk Meningkatkan Hasil Belajar IPS Kelas VI SD". Hasil penelitian menunjukkan bahwa dapat meningkatkan hasil belajar siswa kelas VI SDN 6 Kubutambahan. Rata-rata hasil belajar pada siklus I mencapai 65 dan pada siklus II mencapai 75, mengalami peningkatan sebesar 10 poin, ketuntasan belajar sebelum tahap penelitian sebesar $52 \%$ meningkat setelah penerapan siklus I menjadi $67 \%$ ini berarti mengalami peningkatan sebesar 15\%, dari siklus I ke siklus II ketuntasan belajar mencapai $93 \%$ ini berarti mengalami peningkatan $26 \%$.

Penelitian yang dilakukan oleh Nuryati Volume 4 Nomor 2 tahun 2015 dimuat dalam Jurnal Primary Program Studi Pendidikan Guru Sekolah Dasar Fakultas Keguruan dan Ilmu Pendidikan Universitas Riau dengan judul "Penerapan Model Pembelajaran Quantum Teaching untuk Meningkatkan Hasil Belajar IPA Siswa Kelas V SD Negeri 24 Pekanbaru". Hasil penelitian menunjukkan bahwa nilai UH pada skor dasar 65,38 kemudian menjadi 85,54 dengan peningkatan sebesar 30,84\%. Ketuntasan belajar siswa secara klasikal mengalami peningkatan pada setiap siklus. Pada skor dasar ketuntasan belajar siswa 42,31\% (kategori tidak tuntas), pada siklus I meningkat menjadi $61,54 \%$ (kategori tidak tuntas) dan pada siklus II juga meningkat menjadi 88,46 (kategori tuntas).

Persentase aktivitas guru mengalami peningkatan. Pada siklus I pertemuan pertama $66,7 \%$ (cukup), pada pertemuan kedua meningkat menjadi 75\% (baik). Pada siklus II pertemuan pertama $83,3 \%$ (baik), kemudian pada pertemuan kedua meningkat menjadi 95,8\% (sangat baik). Penelitian yang dilakukan oleh Kukuh Andri Eka (2016) dengan judul " model quantum teaching dengan pendekatan cooperative learning untuk meningkatkan kualitas pembelajaran PKn". hasil belajar siswa mengalami peningkatan. Dimulai dari siklus I pertemuan 1 yaitu $78 \%$, siklus I pertemuan 2 mendapatkan $80 \%$, siklus II pertemuan 1 mendapatkan $88 \%$, dan siklus II pertemuan 2 mendapatkan 94\%, sedangkan ketuntasan klasikal secara berurutan memperoleh $82 \%, 86 \%$, $91 \%$, dan $96 \%$, artinya siklus I pertemuan 1 masih ada 4 siswa di bawah KKM, kemudian siklus I pertemuan 2 ada 3 siswa, siklus II 
pertemuan 1 ada 2 siswa, dan siklus II pertemuan 2 sejumlah 1 siswa. Berdasarkan uraian tersebut, penggunaan model Quantum Teaching menggunakan powerpoint efektif diterapkan pada pembelajaran PKn materi globalisasi dengan tujuan untuk melatih siswa dalam berpikir aktif, kreatif maupun kritis dalam menanggapi suatu permasalahan yang berkaitan dengan kehidupan nyata.

\section{Aktivitas Siswa}

Aktivitas siswa kelas eksperimen dan kelas kontrol perlu dibandingkan untuk mengetahui perbedaan dari keduanya. Hasil perhitungan rata-rata aktivitas siswa antara kelas eksperimen dan kelas kontrol disajikan pada diagram sebagai berikut:

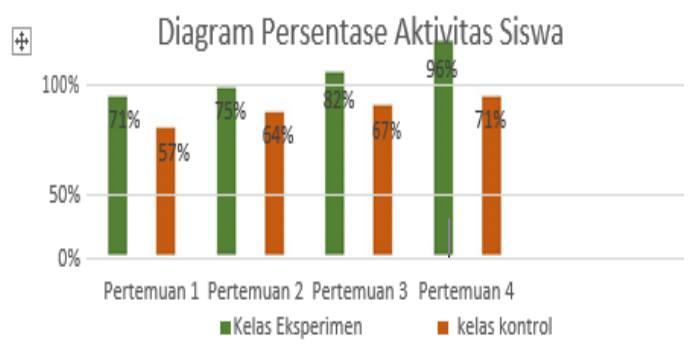

Diagram 1. Perbandingan Rata-Rata Aktivitas Kelas Eksperimen dan Kontrol

Berdasarkan diagram tersebut, terlihat bahwa aktivitas siswa kelas eksperimen cenderung lebih baik daripada aktivitas siswa kelas kontrol. Rata-rata aktivitas siswa kelas eksperimen dari empat pertemuan yaitu $82 \%$ siswa mengikuti pelajaran dengan baik. Sedangkan, rata-rata aktivitas siswa kelas kontrol dari empat pertemuan yaitu $64,75 \%$ siswa mengikuti pelajaran dengan baik. Hal tersebut menunjukkan bahwa pembelajaran dengan model Quantum Teaching menggunakan powerpoint cenderung meningkatkan aktivitas siswa untuk berpikir aktif maupun kritis bila dibandingkan dengan menggunakan model konvensional yaitu metode ceramah dan tanya jawab. Model Quantum Teaching menggunakan powerpoint memberikan pengaruh positif pada pembelajaran PKn. Pengaruh positif berupa peningkatan nilai posttest materi globalisasi dan aktivitas siswa. Keefektifan model Quantum Teaching menggunakan powerpoint pada pembelajaran PKn materi globalisasi sesuai dengan teori belajar kognitif yang menyatakan bahwa pada jenjang SD anak masih dalam tahap operasional konkret yaitu membutuhkan situasi nyata untuk membangun pengetahuan dan membentuknya menjadi sebuah pemahaman.

Secara umum model Quantum Teaching menggunakan powerpoint efektif digunakan pada pembelajaran PKn materi globalisasi. Model Quantum Teaching menggunakan powerpoint dapat meningkatkan hasil belajar PKn serta meningkatkan aktivitas siswa selama kegiatan pembelajaran berlangsung.

\section{SIMPULAN}

Simpulan dalam penelitian ini adalah model Quantum Teaching menggunakan powerpoint lebih efektif terhadap hasil belajar PKn materi globalisasi kelas IV SDN Gugus Kartini Kecamatan Wirosari Kabupaten Grobogan. Keefektifan model Quantum Teaching menggunakan powerpoint ditunjukkan dari perbedaan nilai posttest dan aktivitas siswa baik kelas eksperimen maupun kelas kontrol. Ratarata posttest kelas eksperimen sebesar 78,79, sedangkan kelas kontrol sebesar 69,24. Selanjutnya, rata-rata aktivitas siswa kelas eksperimen yaitu $85 \%$ dan kelas kontrol yaitu $64,75 \%$.

\section{UCAPAN TERIMA KASIH}

Penulis mengucapkan terimakasih kepada kedua orang tua yang telah memberikan semangat dan dukungan doa. Farid Ahmadi.,M.Kom.,Ph.D., mitra bestari I Susilo Tri Widodo, S.Pd., M.Pd., mitra bestari II Harmanto, S.Pd., M.Pd serta penyunting bahasa inggris Dra. Nuraeni Abbas, M.Pd., yang telah 
memberikan bimbingan dan koreksi pada artikel ini.

\section{DAFTAR PUSTAKA}

Adawiyah Fitri, dkk. 2015. Aplication Quantum Teaching Model to Develoved Student Activity to Socal Studies in Elementary School. Antologi Vol 3 No 2.

Bestari, Prayoga dan Ati Sumiati. 2008. Pendidikan Kewarganegaraan: Menjadi Warga Negara yang Baik untuk Kelas IV Sekolah Dasar/Madrasah Ibtidaiyah. Jakarta: Pusat Perbukuan Departemen Pendidikan Nasional.

BSNP. 2006. Standar Isi untuk Satuan Pendidikan Dasar dan Menengah Standar Kompetensi dan Kompetensi Dasar SD/MI. Jakarta: Depdikbud.

DePorter, Bobbi, dkk. 2014. Quantum Teaching. Bandung: Kaifa.

Huda, Miftahul. 2014. Model-Model Pengajaran dan Pembelajaran. Yogyakarta: Pustaka Pelajar.

Hamalik, Oemar. 2013. Proses Belajar Mengajar. Jakarta: Bumi Aksara.

Hadi,syamsul. 2008. Microsoft power point

Surabaya: Tiara aksa.

Huda, Miftahul. 2014. Model-Model Pengajaran dan Pembelajaran. Yogyakarta: Pustaka Pelajar.

Hamalik, Oemar. 2013. Proses Belajar Mengajar. Jakarta: Bumi Aksara.

Kholisul Fatikhin, Muhammad \& M. Kristanto. 2014. Keefektifan Model Quantum Teaching Terhadap Hasil Belajar Tematik Integratif Peserta Didik Kelas IV MII. Mimbar Sekolah Dasar Vol 1 No 2 (hal.123-127).

Koeswandi dan Mursid Saleh. 2014. Developing an English Instructional Model of Reading Comprehension Using Quantum Teaching Model for Junior High School. Jurnal Pengembangan Humaniora Vol 14 No 2.
Nuryati. 2015. Penerapan Model Pembelajaran Quantum Teaching untuk Meningkatkan Hasil Belajar IPA Siswa Kelas V SD Negeri 24 Pekanbaru. Jurnal Primary Program Studi Pendidikan Guru Sekolah Dasar

Fakultas Keguruan dan Ilmu Pendidikan Universitas Riau ISSN: 2303-1514 Vol 4 No 2.

Peraturan Pemerintah Nomor 32 tahun 2013 pasal 19 tentang Proses Pembelajaran.

Putu Cahyadi, Dewa, dkk. 2014. Implementasi Model Quantum Teaching Berbantuan Snowball Trhowing untuk Meningkatkan Hasil Belajar IPS Kelas VI SD. Jurnal Mimbar PGSD Universitas Ganesha Vol 2 No 1.

Shoimin, Aris. 2014. 68 Model Pembelajaran Inovatif dalam Kurikulum 2013.

Sugiyono. 2015. Metode Penelitian Pendidikan Pendekatan Kuantitatif, Kualitatif, dan $R \& D$. Bandung: Alfabeta.

Undang-Undang Dasar Nomor 20 Tahun 2003 tentang Sistem Pendidikan Nasional.

Winataputra, Udin S. 2008. Materi dan Pembelajaran $P K n \quad S D$. Jakarta: Universitas Terbuka.

Wigati Fitria Asih. 2016. The Effect of The Implementation of Quantum Teaching Strategi in Teaching Writing a Descriptive Text. Jurnal Pendidikan UNSIKA Vol 4 No 1.

Winarti Durant, Sri, dkk. 2014. Meningkatkan Hasil Belajar IPA Khususnya Materi Energi dan Perubahannya Melalui Pembelajaran Quantum Teaching di Kelas $V$ SDN Inpres Matamaling. Jurnal Kreatif Tadulako ISSN 2354-614X Vol $2 \quad$ No 3. 
